\title{
Rice Machinery Requirement in La Union, Philippines: A Basis for Prioritizing Deployment
}

\author{
Rosalinda L. Abad \\ Don Mariano Marcos Memorial State University, La Union, Philippines, \\ https://orcid.org/0000-0003-1314-8939 \\ Email Correspondence: rabad@dmmmsu.edu.ph
}

\begin{abstract}
The implementation of the Republic Act No. 11203 mandates the development of a just and appropriate agricultural mechanization strategy. Thus, this study is conceptualized to calculate the rice machinery requirement and the mechanization level of La Union, Philippines. The utilization rate of existing machinery considers $100 \%$ and $70 \%$ in case the calculation is surplus. Furthermore, this aims to validate if there is no machinery requirement despite the $30 \%$ decrease in utilization rate. Hence, the results have revealed a need for 674 units of riding-type transplanters, 31 units of a rice combine harvester, 422 units of recirculating dryers, and 61 units of multi-pass rice mills. The rice mechanization level is moderately mechanized. However, only tillage operation is moderately mechanized; the transplanting, harvesting, drying and milling are low mechanised. These findings could serve as bases in the formulation of policies and strategies prioritizing suitable areas for machinery intervention in the province.
\end{abstract}

Keywords:agricultural engineering, agricultural machinery, mechanization level, Philippines

\subsection{Introduction}

Rice (Oryza sativa) is the main staple and most valuable crop in the Philippines ("FAO Regional Rice Initiative", n.d. ; Casinillo, 2020). Its cultivation provides livelihood to 2.5 million households having 2.1 million farmers, 110,000 workers for postproduction activities, and 320,000 workers for supplementary activities. The country is known as the eighth-largest rice producer globally, producing 19.07 MT in 2018. However, despite this production volume, it is one of the largest importers, importing 0.89 MMT of rice or P18.03 billion in 2017 (Philippine Statistics Authority [PSA], 2018). From 2000 to 2015, the difference between total milled rice production and total milled rice consumption was -1,642,750 MT (Exconde, 2016). It is attributed to the growing population from $88,546,543$ to $100,979,903$ with a growth rate of $1.7 \%$ annually (PSA, 2020).

The increasing population demands an increase in production (Food and Agriculture Organization of the United Nations [FAO], 2017). With this, fast-tracking agricultural development through agricultural mechanization could be one intervention (Emami et al., 2018). However, the mechanization level in 2011 for rice and corn was $2.31 \mathrm{hp} / \mathrm{ha}$, of which human labor is $0.39 \mathrm{hp} /$ ha, draft animals are $0.39 \mathrm{hp} / \mathrm{ha}$, and mechanical 
power is $1.77 \mathrm{hp} / \mathrm{ha}$. Adding all staple crops, the mechanization level decreases at $1.23 \mathrm{hp} / \mathrm{ha}$ (Dela Cruz \& Bobier, 2016). This current mechanization level is low mechanized compared to other countries like India and China at 3.88 and $2.55 \mathrm{hp} /$ ha (Hegazy \& Okasha, 2020).

Postharvest losses also contribute to the problems of increasing rice sufficiency. From the research conducted by PHilMech, the postharvest losses could reach as high as $14.84 \%$ of the total production (Regalado \& Ramos, 2018). These losses emanate from manual harvesting of $1.81 \%$, piling of $0.54 \%$, threshing of $2.17 \%$, drying of $4.5 \%$, and storage of $2.72 \%$. Another is from the research collaborated by PhilRice and PHilMech from 2007 to 2009, postharvest losses from harvesting, piling, threshing, drying, and milling operations could reach as high as $14.42 \%$ during the dry season and higher during the wet season of $14.84 \%$.

Aside from low mechanization levels, there is also an unstoppable trend in the shortage of manual labor and increasing labor costs. In 1995-1996, the number of agricultural laborers exceeded, however, declines in 1997. And since 2011, the number of laborers declines consistently in an average of 250,000 workers per year (Briones, 2017). Farmers educate their children and encourage them to work on non-farming jobs in urban areas or abroad (Palis, 2020). With this, the average age of rice farmers was 59 years old in 2012 from 46 years old in 1966 (Moya et al., 2015). This problem of aging farmers could later contribute to the shortage of labor in the coming years.

To mitigate these concerns, the government had formulated laws to increase productivity and sustainability in production. One of these laws is the Republic Act No. 11203, which established the Rice Competitiveness Enhancement Fund (RCEF), allocating financial support annually of $P 10$-billion for the next six years beginning 2019 (National Economic and Development Authority [NEDA],
2019). Moreover, to provide a just and appropriate mechanization strategy, there is a need to calculate machinery requirements and mechanization levels. Hence, failure to recognize the actual needs of the farmers results in the non-adoption of machines. Also, unsuitability and adopting bigger size and capacity of the machinery are against the principles of economies of scale (Philipppine Council for Agriculture, Forestry, and Natural Resources Research and Development [PCARRD], 2009).

The entry and backbone of machinery deployment is the selective use of mechanization technologies for better productivity (Amare \& Endalew, 2016). Thus, a need to develop a strategy calculating the rice machinery requirement as a basis for machinery deployment is necessary. As such, this study aims to determine the rice machinery requirement in La Union, Philippines, as a basis for prioritizing machinery deployment. Specifically, it seeks to answer the following specific objectives: (1) to describe the agricultural profile in the province; (2) to determine the rice farming operations needing machinery deployment; and (3) to calculate the mechanization level in the Province of La Union.

The results of this study purposely aim to assist the policy implementers, the Department of Agriculture- Regional Field Office 1, as well as the Provincial and Municipal Agriculturist Offices in the La Union in formulating mechanization strategy of prioritizing areas needing machinery deployment that would later contribute to the increase in the volume of production, improving farmers' lives, and achieving food security.

\section{Conceptual Framework}

The conceptual framework of the study used the mechanization level as one of the quantifiable methods by which the mechanization degree of the different farming operations within a 
limit can be evaluated (Hegazy \& Okasha, 2020). The mechanization level is the total number of mechanized field operations and the mechanical power used in the unit of field operation expressed in hp/ha (Soni \& Ou, 2010). The machinery requirement calculation was from Sharabiani and Ranjbar (2008), which calculates the number of tractors and other machinery using the inverse procedure of mechanization level calculation. The mechanization level equation in $\mathrm{hp} / \mathrm{ha}$ adopted from Maheshwari and Tripathi (2019) is expressed as:

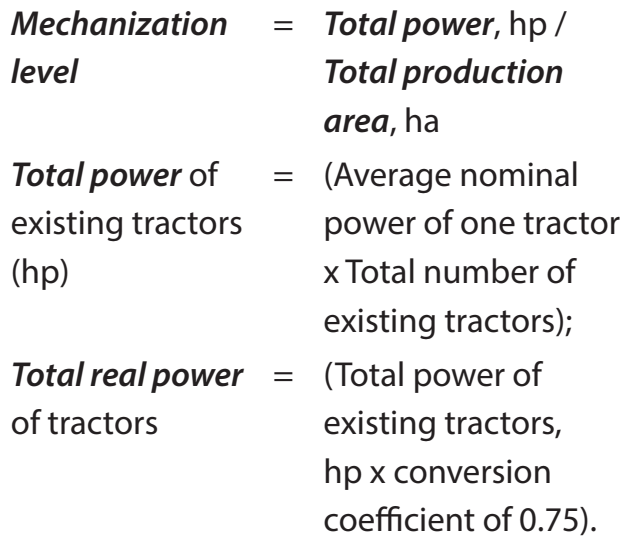

More recent models estimating mechanization indicators are the Mechanization Index (MI) and Mechanical Energy Ratio (MER). To use these models, the data from the different farming operations gathered from farmers, machinery suppliers, researchers, and government officials will be utilized (Ramirez et al., 2007).

\subsection{Research Design and Methodology}

The study utilized the descriptive research and employed the quantitative approach in identifying the agricultural profile, determining the rice machinery requirement, and the mechanization level in the province of La Union as a basis for prioritizing machinery deployment. Specifically, request letters were distributed to gather rice machinery inventory data and agricultural profiles in the Province of La Union. Correspondingly, the quantitative methods and descriptive statistics in the analysis and presentation of results were used.

\section{Instrumentation and Data Collection}

The data were gathered from the different agencies through forwarding of request letters with attached benchmarking data sheet to concerned agencies. The collection datasheet to the National Irrigation Administration (NIA) specified the 2019 rice production area in hectares (ha) for irrigated and non-irrigated/rainfed areas per municipality in the province. The Department of Agriculture - Regional Field Office 1 (DA-RFO1) specified the updated data for the 2019 annual rice production in metric tons/year for dry basis and wet basis production per municipality. The Office of the Department of Agriculture - Philippine Center for Postharvest Development and Mechanization (DA- PHilMech) specified the 2018 provincial machinery inventory per field operations per municipality; such as, tillage operation for the number of available units for four-wheel tractor and hand tractor; transplanting operation for walk-behind type transplanter and riding type transplanter; harvesting operation for combine harvester, thresher, and reaper; drying operation for the recirculating dryer, flatbed dryer, and MultiPurpose Drying Pavement (MPDP); and milling operation for single-pass rice mill and multi-pass rice mill.

\section{Data Analysis}

The analysis was largely dependent on the secondary data collected, tabulated, and finalized for calculation. The calculation of farming operations needing mechanization used two (2) croppings per year. The available production area was projected to be planted all year round. Also, all the existing rice machineries were assumed to be 
functional or utilized all year round. The utilization rate calculation of machinery was at $100 \%$. This was done to calculate the number of deficit/needed and surplus agricultural machinery of the province at the maximum number of units. However, in the case of surplus machinery, it was also calculated at a $70 \%$ utilization rate. Purposely, this aimed to validate if there is no machinery deployment despite the $30 \%$ decrease in the utilization rate of existing machinery.

Table 1.Parameters used in the calculation of rice machinery requirement and mechanization level in the province

\begin{tabular}{|c|c|c|c|c|c|c|c|}
\hline \multirow[t]{2}{*}{ Sources of Power } & $S$ & W & TFC & $\mathrm{FE}$ & $\begin{array}{l}\text { Operating } \\
\text { Time }\end{array}$ & $\begin{array}{c}\text { Annual } \\
\text { Operation }\end{array}$ & $\begin{array}{c}\text { Average } \\
\text { Available } \\
\text { Power }\end{array}$ \\
\hline & $\begin{array}{l}\mathrm{km} / \mathrm{hr} \& \\
\text { MT/day* }\end{array}$ & $\begin{array}{c}\mathrm{m} \& \\
\mathrm{hr}\end{array}$ & $\begin{array}{l}\text { ha/hr \& } \\
\text { MT/hr* }\end{array}$ & $\%$ & $\mathrm{hr} /$ day & days/yr & $\mathrm{HP}$ \\
\hline Human & & & & & & & 0.1 \\
\hline Four-Wheel Tractor & 6.0 & 1.5 & 0.72 & 0.8 & 8 & 60 & 52.5 \\
\hline Hand Tractor & 4.0 & 1.2 & 0.38 & 0.9 & 8 & 60 & 9.5 \\
\hline $\begin{array}{l}\text { Walk-Behind } \\
\text { Transplanter }\end{array}$ & 3.0 & 1.2 & 0.29 & 0.9 & 8 & 60 & 5.5 \\
\hline $\begin{array}{l}\text { Riding-type } \\
\text { Transplanter }\end{array}$ & 3.0 & 1.5 & 0.36 & 0.8 & 8 & 60 & 5.5 \\
\hline Thresher & - & - & $1.0^{*}$ & 0.74 & 8 & 60 & 16.0 \\
\hline Reaper & 2.0 & 1.5 & $1.1^{*}$ & 0.65 & 8 & 60 & 5.0 \\
\hline Combine Harvester & 5.58 & 1.9 & $3.88^{*}$ & 0.75 & 8 & 60 & 60.0 \\
\hline Recirculating Dryer & $6.0 *$ & $6.0 *$ & $1.0^{*}$ & 0.75 & 8 & 60 & 12.5 \\
\hline Flatbed Dryer & $6.0^{*}$ & $12.7 *$ & $0.5^{*}$ & 0.75 & 12 & 60 & 12.5 \\
\hline $\begin{array}{l}\text { Multi-Purpose Drying } \\
\text { Pavement }\end{array}$ & $4.0 *$ & $12.7 *$ & $0.3^{*}$ & 0.75 & 6 & 60 & - \\
\hline Single-Pass Rice Mill & - & - & $0.7^{*}$ & 0.65 & 12 & 120 & 20.0 \\
\hline Multi-Pass Rice Mill & - & - & $1.7^{*}$ & 0.75 & 12 & 120 & 70.0 \\
\hline
\end{tabular}

Sources:

Human-Makange (2015)

Field Efficiency-PAES 109: 2000 for walking-type agricultural tractor, PAES 118:2001 for four-wheel tractor; PAES 151:2015 for rice transplanter; PAES 212:2015 for rice reaper, PAES 204:2015 for rice thresher; PAES 224:2015 for combine harvester; PAES 201:2015 for dryers; and PAES 206:2015 for rice mills (University of the Philippines Los Banos. College of Engineering and Agro-Industrial Technology. Agricultural Machinery Testing and Evaluation Center, 2000; 2001; 2015).

Average Available Power - Department of Agriculture (2019) 
The parameters used in the calculation of rice machinery requirement are shown in Table 1. The operating speed (S) in $\mathrm{km} / \mathrm{hr}$, input capacity of none moving machinery in metric tons/day, and working width (W) of moving machinery expressed theoretically, assuming that the machine is working at $100 \%$ efficiency. However, due to time efficiency such as turning time on headlands, maintenance time, repair time (if any), operator's personal time, the machine is not operating at $100 \%$ efficiency (American Society of Agricultural Engineers [ASAE], 2000). Thus, the field efficiency (FE) stated in PAES is adopted in the calculation. The operating time in hrs/day is assumed to be the maximum working time per day. The annual operation in days/year considers the practice of two (2) cropping's/year multiplied it to operation days per cropping. The drying time is the duration that rice dried from $28 \%$ moisture content (Fresh Weight) to $14 \%$ moisture content (Dry Weight) (Ramos et al., 2013). The moisture reduction of $14 \% \mathrm{MC}$ is the desirable requirement for milling. The annual operating time was based on the rice planting calendar in the province and assumed to be the maximum duration for the harvesting, drying, and milling of the total production.

For the step-by-step mechanization level calculation expressed in $\mathrm{hp} / \mathrm{ha}$, the following utilized Equations are 1, 2, 3, 4, and 5. Equation 1, the Effective Field Capacity, EFC, is the actual rate of operation. It is usually lower than the Theoretical Field Capacity (TFC) due to delays during field operation (Hanna, 2016). The EFC considers the non-operating time of the machine. Equation 2 is the yearly machine capacity/annual machine capacity, expressed in ha is the total area operated for moving machinery (ha/yr.) and volume of rice dried and milled of non-moving machinery (MT/ yr.). Equation 3, TEC in hectares, is the capacity of total existing machinery utilized in the province per field operation. The TEC computed per machine, then per operation considering the yearly machine capacity or Yc.
Equation 4 is the deficit and surplus machinery $(D / S)$ expressed in the number of units needed or surplus in the province. The calculated surplus machinery is the number of existing machinery that is not fully utilized considering the production area. If the calculation is surplus, it means that intervention of machinery is not encouraged. Equation 5 adopted from Sharabiani and Ranjbar (2008) is the mechanization level, expressed in $\mathrm{hp} / \mathrm{ha}$, which is the number of mechanized field operations and the power of machines employed in the unit of field operation.

The calculated mechanization level in $\mathrm{hp} /$ ha was expressed according to the three (3) classifications of mechanization adopted from Bermudez et al. (2004). The following are:

a. low mechanized if the calculated mechanization level is at 0.1 to $0.9 \mathrm{hp} / \mathrm{ha}$,

b. moderate mechanized if the calculated mechanization level is 0.9 to $3.0 \mathrm{hp} / \mathrm{ha}$, and;

c. high mechanized if the calculated mechanization level is 3.0 to $5.5 \mathrm{hp} / \mathrm{ha}$.

The low mechanized level means operation with the use of non-mechanical power such as man and animal; moderate mechanized means operation with non-mechanical and mechanical sources; and high mechanized means operation solely with the mechanical sources or operation with limited human intervention such as computerized robots (Amongo et al., 2011).

$\mathrm{EFC}=\mathrm{SWEff} / \mathrm{C}$

where:

$\mathrm{EFC}=$ Effective Field Capacity, ha/hr

$\mathrm{S}=$ Speed of operation, $\mathrm{km} / \mathrm{hr}$

$\mathrm{W}=$ Working width, $\mathrm{m}$

Eff = Efficiency (Efficiency of machinery based on PAES)

$\mathrm{C}=$ Conversion factor, 10 
$\mathrm{Yc}=\mathrm{EFC} \times \mathrm{Op}_{\mathrm{s}} \times \mathrm{EFC}_{\mathrm{s}} \times \mathrm{S}_{\mathrm{y}}$

where:

$\mathrm{Y}_{\mathrm{C}}=$ Yearly Machine Capacity, ha

$\mathrm{EFC}=$ Effective Field Capacity, ha/hr

$\mathrm{OP}_{\mathrm{s}}=$ Operating Days per Cropping, days/

cropping

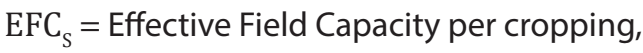

ha/cropping

$\mathrm{S}_{\mathrm{y}}=$ Number of Cropping Season per Year, cropping/yr

$\mathrm{TEC}=\left(\mathrm{N}_{1} \times \mathrm{Y}_{1}\right)+\ldots .+\left(\mathrm{N}_{\mathrm{n}} \times \mathrm{Y}_{\mathrm{n}}\right)$

where:

TEC=Total Existing Capacity per Field

Operation, ha

$\mathrm{N}_{1}=$ Number Existing Units of Four-Wheel

Tractor

$\mathrm{Y}_{1}=$ Yearly machine capacity of Four-Wheel

Tractor, ha

$\mathrm{N}_{\mathrm{n}}=$ Nth number of existing units of

machine

$\mathrm{Y}_{\mathrm{n}}=\mathrm{N}$ th number of yearly machine capacity, ha

$\mathrm{D} / \mathrm{S}=(\mathrm{TPA}-\mathrm{TEC}) / \mathrm{Y}_{\mathrm{c}}$

where:

$\mathrm{D} / \mathrm{S}=$ Total Number of Needed or Surplus

Machinery, number of units

TPA $=$ Total Production Area, ha

TEC $=$ Total Existing Capacity per Field

Operation, ha

$\mathrm{Y}_{\mathrm{c}}=$ Yearly Machine Capacity, ha

$\mathrm{M}_{\mathrm{L}}=(\mathrm{TPA}+\mathrm{H} / \mathrm{TPA})$

where:

$\mathrm{M}_{\mathrm{L}}=$ Mechanization Level, hp/ha

TPA $=$ Total Power of Available/Existing

Machines, hp

$\mathrm{H}=$ Total Human Power, $\mathrm{hp}$

$\mathrm{TPA}=$ Total Production Area, ha
(2) 3.0 Results

Agricultural Profile of the Province of La Union

The province of La Union is in the northeastern part of llocos Region comprising of 19 municipalities and one (1) city: Agoo, Aringay, Bacnotan, Bagulin, Baloan, Bangar, Bauang, Burgos, Caba, Luna, Naguilian, Pugo, Rosario, City of San Fernando, San Gabriel, San Juan, Sto. Tomas, Santol, Sudipen, and Tubao. It has a total land area of 150,400 ha and a total population of 786,653 . It belongs to Type 3 climate with two distinct seasons, dry and wet that is cooler from December to February and hottest from April to May. The provincial economy depends on agriculture planting crops such as rice, onion, tobacco, corn, sugarcane, fruits, and livestock raising of pigs, chicken, goats, and carabaos.

Rice is the major crop, with a total production area of 29,204 ha. The irrigated area is only 15,380 ha while the non-irrigated or rainfed is 13,824 ha. The number of farmers cultivating rice is 44,929 that is $5.71 \%$ of the population. The annual volume of production on a wet basis is 188,318.85 MT (162,050.47 MT dry basis), equivalent to $38.52 \%$ of the annual rice production in Region 1 of 488,855 MT.

The total number of existing rice machinery is 3,314 units of tillage operation, specifically 2,979 units of hand tractor and 335 units of the fourwheel tractor. The transplanting has a total of only 12 units of transplanters. The harvesting operation has 824 units of thresher, 55 units of the reaper, and 17 units of the combine harvester. For drying operations, the machinery utilized includes 111 units of Multi-Purpose Drying Pavement (MPDP), 52 units of the flatbed dryer, and one (1) unit of the recirculating dryer. For milling operation, it has a total of four (4) units single-pass rice mill. 
Rice Farming Operation Needing Machinery have a deficit of 18 units of four-wheel tractors. The Deployment

Tillage Operation Machinery Requirement other eight (8) municipalities and the City of San

The tillage operation in the province is purely Fernando have surpluses of four-wheel tractors. mechanically powered that no animal is involved. From the result, at a $100 \%$ utilization rate, as shown in Table 2, most of the municipalities have a surplus of hand tractors totaling 2,849 units. The nine (9) municipalities have surplus four-wheel tractors After decreasing the utilization rate at $70 \%$, the number of tillage machinery is still surplus of 45 units of four-wheel tractors and 1,915 units of hand tractor. However, the three (3) municipalities, Aringay, San Gabriel, and Santol, have a total deficit of 23 units of four-wheel tractors.

totaling 132 units, while San Gabriel and Santol

Table 2. Tillage operation machinery requirement at $100 \%$ and $70 \%$ utilization rate

\begin{tabular}{|c|c|c|c|c|c|c|c|}
\hline \multicolumn{5}{|c|}{$100 \%$ Utilization Rate } & \multicolumn{3}{|c|}{ 70\% Utilization Rate } \\
\hline Municipality & $\begin{array}{l}\text { Capacity } \\
\text { of Existing } \\
\text { Machinery } \\
\text { (ha/yr) }\end{array}$ & $\begin{array}{l}\text { Production } \\
\text { Area (ha/yr) }\end{array}$ & $\begin{array}{l}\text { Four } \\
\text { Wheel } \\
\text { Tractor }\end{array}$ & $\begin{array}{l}\text { Hand } \\
\text { Tractor }\end{array}$ & $\begin{array}{l}\text { Capacity } \\
\text { of Existing } \\
\text { Machinery } \\
\text { (ha) }\end{array}$ & $\begin{array}{l}\text { Four } \\
\text { Wheel } \\
\text { Tractor }\end{array}$ & $\begin{array}{l}\text { Hand } \\
\text { Tractor }\end{array}$ \\
\hline Agoo & $40,193.28$ & 2,974 & 0 & 317 & $28,135.30$ & 0 & 215 \\
\hline Aringay & $3,207.17$ & 2,820 & 0 & 4 & $2,245.02$ & $/ 3 /$ & 0 \\
\hline Bacnotan & $46,642.18$ & 3,766 & 46 & 284 & $32,649.52$ & 27 & 199 \\
\hline Bagulin & $14,805.50$ & 1492 & 0 & 114 & $10,363.85$ & 0 & 76 \\
\hline Balaoan & $46,946.30$ & 3,744 & 52 & 276 & $32,862.41$ & 31 & 194 \\
\hline Bangar & $15,455.23$ & 3,832 & 1 & 98 & $10,818.66$ & 0 & 60 \\
\hline Bauang & $6,759.94$ & 3,444 & 3 & 24 & $4,731.96$ & 0 & 11 \\
\hline Burgos & $3,055.10$ & 1538 & 0 & 13 & $2,138.57$ & 0 & 6 \\
\hline Caba & $7,658.50$ & 2,302 & 1 & 44 & $5,360.95$ & 0 & 27 \\
\hline Luna & $33,426.43$ & 3,620 & 0 & 254 & $23,398.50$ & 0 & 169 \\
\hline Naguilian & $63,389.95$ & 4,380 & 28 & 453 & $44,372.97$ & 14 & 318 \\
\hline Pugo & $4,582.66$ & 1520 & 0 & 27 & $3,207.86$ & 0 & 15 \\
\hline Rosario & $25,781.76$ & 4,112 & 0 & 185 & $18,047.23$ & 0 & 119 \\
\hline San Fernando City & $6,324.48$ & 3,576 & 0 & 24 & $4,427.14$ & 0 & 8 \\
\hline San Gabriel & 470.02 & 2,136 & /9/ & 0 & 329.01 & /9/ & 0 \\
\hline San Juan & $10,139.90$ & 3,816 & 2 & 51 & $7,097.93$ & 0 & 28 \\
\hline Sto. Tomas & $18,572.54$ & 2,154 & 0 & 141 & $13,000.78$ & 0 & 93 \\
\hline Santol & 352.51 & 2,074 & /9/ & 0 & 246.76 & $/ 10 /$ & 0 \\
\hline Sudipen & $44,402.69$ & 2,848 & 13 & 332 & $31,081.88$ & 0 & 233 \\
\hline Tubao & $27,343.87$ & 2,260 & 4 & 208 & $19,140.71$ & 0 & 144 \\
\hline Total & $419,510.02$ & 58,408 & $\begin{array}{c}132 \text { and } \\
/ 18 /\end{array}$ & 2,849 & $293,657.01$ & $\begin{array}{c}45 \text { and } \\
/ 23 /\end{array}$ & 1,915 \\
\hline
\end{tabular}


Transplanting Operation Machinery Requirement is high because the ten (10) municipalities do

The transplanting operation in the province is mostly done manually. From the result, at $100 \%$ utilization rate the province is in need of 674 units of riding-type transplanter as shown in Table 3. The transplanting machinery deficiency not have existing transplanting machinery. Even some of the municipalities have existing units of transplanters, still, all municipalities are deficit with planting machinery. The results imply deployment of planting machinery to all municipalities.

Table 3. Transplanting operation machinery requirement at 100\% utilization rate

\begin{tabular}{lccc}
\hline Municipality & $\begin{array}{c}\text { Capacity of Existing } \\
\text { Machinery (ha/yr) }\end{array}$ & $\begin{array}{c}\text { Production Area } \\
\text { (ha/yr) }\end{array}$ & $\begin{array}{c}\text { Riding-type } \\
\text { Transplanter }\end{array}$ \\
\hline Agoo & 117.3 & 2,974 & $/ 34 /$ \\
Aringay & 0 & 2,820 & $/ 33 /$ \\
Bacnotan & 117.3 & 3,766 & $/ 43 /$ \\
Bagulin & 0 & 1492 & $/ 18 /$ \\
Balaoan & 138.24 & 3,744 & $/ 43 /$ \\
Bangar & 372.84 & 3,832 & $/ 42 /$ \\
Bauang & 0 & 3,444 & $/ 40 /$ \\
Burgos & 0 & 1538 & $/ 18 /$ \\
Caba & 0 & 2,302 & $/ 27 /$ \\
Luna & 0 & 3,620 & $/ 42 /$ \\
Naguilian & 138.24 & 4,380 & $/ 50 /$ \\
Pugo & 0 & 1520 & $/ 18 /$ \\
Rosario & 117.3 & 4,112 & $/ 47 /$ \\
San Fernando City & 117.3 & 3,576 & $/ 41 /$ \\
San Gabriel & 0 & 2,136 & $/ 25 /$ \\
San Juan & 0 & 3,816 & $/ 45 /$ \\
Sto. Tomas & 138.24 & 2,154 & $/ 24 /$ \\
Santol & 0 & 2,074 & $/ 25 /$ \\
Sudipen & 117.3 & 2,848 & $/ 33 /$ \\
Tubao & 117.3 & 2,260 & $/ 26 /$ \\
Total & $\mathbf{1 , 4 9 1 . 3 6}$ & $\mathbf{5 8 , 4 0 8}$ & $/ 674 /$ \\
\hline
\end{tabular}

\section{Harvesting Operation Machinery Requirement}

From the result of $100 \%$ utilization rate, as shown in Table 4, the 14 municipalities were found to have 595 units surplus of threshers. On the other hand, for the City of San Fernando and Bauang, Burgos, San Gabriel, San Juan, and Sto. Tomas have a deficit of 20 units of rice combine harvesters. Furthermore, given the scenario of $70 \%$ utilization, the province is still surplus of 327 surplus units of threshers. However, 31 units of rice combine harvesters for the City of San Fernando, Aringay, Bagulin, Bauang, Burgos, Caba, San Gabriel, San Juan, and Sto. Tomas are needed. With these, only municipalities with deficit harvesting machinery are for deployment. 
Table 4. Harvesting operation machinery requirement at $100 \%$ and $70 \%$ utilization rate

\begin{tabular}{|c|c|c|c|c|c|c|c|}
\hline \multicolumn{5}{|c|}{$100 \%$ Utilization Rate } & \multicolumn{3}{|c|}{ 70\% Utilization Rate } \\
\hline Municipality & $\begin{array}{c}\text { Capacity } \\
\text { of Existing } \\
\text { Machinery (MT) }\end{array}$ & $\begin{array}{l}\text { Volume of } \\
\text { Production } \\
\text { (MT/year) }\end{array}$ & $\begin{array}{l}\text { Combine } \\
\text { harvester }\end{array}$ & Thresher & $\begin{array}{l}\text { Capacity } \\
\text { of Existing } \\
\text { Machinery } \\
\text { (MT) }\end{array}$ & $\begin{array}{l}\text { Combine } \\
\text { harvester }\end{array}$ & Thresher \\
\hline Agoo & $52,009.31$ & $14,763.06$ & 0 & 78 & $36,406.52$ & 0 & 46 \\
\hline Aringay & $10,226.77$ & $10,097.80$ & 0 & 16 & $7,158.74$ & /3/ & 0 \\
\hline Bacnotan & $37,919.80$ & $11,747.66$ & 0 & 55 & $26,543.86$ & 0 & 31 \\
\hline Bagulin & $4,524.40$ & $3,642.55$ & 0 & 2 & $3,167.08$ & $/ 1 /$ & 0 \\
\hline Balaoan & $36,146.77$ & $9,826.14$ & 0 & 55 & $25,302.74$ & 0 & 33 \\
\hline Bangar & $37,515.58$ & $13,468.88$ & 0 & 51 & $26,260.91$ & 0 & 27 \\
\hline Bauang & $1,920.00$ & $7,317.90$ & /4/ & 0 & $1,344.00$ & /5/ & 0 \\
\hline Burgos & $3,360.00$ & $4,944.50$ & $/ 2 /$ & 0 & $2,352.00$ & $/ 2 /$ & 0 \\
\hline Caba & $8,773.21$ & $6,267.85$ & 0 & 6 & $6,141.25$ & $/ 1 /$ & 0 \\
\hline Luna & $29,484.40$ & $11,720.54$ & 0 & 38 & $20,639.08$ & 0 & 19 \\
\hline Naguilian & $51,662.52$ & $15,635.35$ & 0 & 76 & $36,163.76$ & 0 & 43 \\
\hline Pugo & $22,080.00$ & $6,768.45$ & 0 & 32 & $15,456.00$ & 0 & 19 \\
\hline Rosario & $41,986.94$ & $13,859.43$ & 0 & 59 & $29,390.86$ & 0 & 33 \\
\hline San Fernando City & $3,360.00$ & $8,781.36$ & /4/ & 0 & $2,352.00$ & $/ 5 /$ & 0 \\
\hline San Gabriel & $6,133.71$ & $7,458.57$ & $/ 1 /$ & 0 & $4,293.60$ & $/ 3 /$ & 0 \\
\hline San Juan & $10,022.37$ & $17,476.79$ & /6/ & 0 & $7,015.66$ & /8/ & 0 \\
\hline Sto. Tomas & $25,920.00$ & $3,651.28$ & /3/ & 0 & 0 & $/ 3 /$ & 0 \\
\hline Santol & 0 & $6,093.68$ & 0 & 42 & $18,144.00$ & 0 & 26 \\
\hline Sudipen & $19,688.97$ & $7,676.90$ & 0 & 26 & $13,782.28$ & 0 & 13 \\
\hline Tubao & $35,106.60$ & $7,120.17$ & 0 & 59 & $24,574.62$ & 0 & 46 \\
\hline Total & $437,841.36$ & $188,318.85$ & $/ 20 /$ & 595 & $306,488.95$ & /31/ & 327 \\
\hline
\end{tabular}

Drying and Milling Operations Machinery Requirement

farmers immediately sell to the middlemen traders, and private dryer operators.

The drying and milling operations in the Overall, the rice machinery requirement as province do not have sufficient machinery. The result shown in Table 5 reveals that the province is in need of 422 units of recirculating dryers and 61 units multi-pass rice mills. The need for machinery is high because some of the municipalities do not have existing drying and milling machinery. The results reveal that only $20 \%$ of the total rice production undergone machinery drying. The a basis for prioritizing machinery deployment to be recommended for the policy implementer, the Agricultural Regional and Municipal Offices in the Province of La Union, is shown in Fig. 1. A total of 674 units of riding-type transplanters, 31 units of a rice combine harvester, 422 units of recirculating dryers, and 61 units of multi-pass rice mill is required for deployment. 
Table 5. Drying and milling operations machinery requirement at $100 \%$ utilization rate

\begin{tabular}{lccccccc}
\hline Municipality & $\begin{array}{c}\text { Capacity } \\
\text { of Existing } \\
\text { Machinery } \\
\text { (MT) }\end{array}$ & $\begin{array}{c}\text { Volume of } \\
\text { Production } \\
\text { (MT/year) }\end{array}$ & $\begin{array}{c}\text { Recirculating } \\
\text { Dryer }\end{array}$ & $\begin{array}{c}\text { Capacity } \\
\text { of Existing } \\
\text { Machinery, } \\
\text { MT }\end{array}$ & $\begin{array}{c}\text { Volume of } \\
\text { Production } \\
\text { MT/year }\end{array}$ & $\begin{array}{c}\text { Single- } \\
\text { Pass } \\
\text { Rice } \\
\text { Mill }\end{array}$ & $\begin{array}{c}\text { Multi- } \\
\text { Pass } \\
\text { Rice } \\
\text { Mill }\end{array}$ \\
\hline Agoo & $1,260.47$ & $14,763.06$ & $/ 38 /$ & $6,220.80$ & $11,695.36$ & 0 & $/ 4 /$ \\
Aringay & 255.12 & $10,097.80$ & $/ 28 /$ & 0 & $11,089.75$ & 0 & $/ 5 /$ \\
Bacnotan & $5,355.59$ & $11,747.66$ & $/ 18 /$ & $3,888.00$ & $14,809.93$ & 0 & $/ 3 /$ \\
Bagulin & 0 & $3,642.55$ & $/ 11 /$ & $3,888.00$ & $5,867.34$ & 1 & 0 \\
Balaoan & $8,715.59$ & $9,826.14$ & $/ 4 /$ & $2,332.80$ & $14,723.41$ & 0 & $/ 3 /$ \\
Bangar & $2,250.71$ & $13,468.88$ & $/ 32 /$ & $9,331.20$ & $15,069.48$ & 0 & $/ 2 /$ \\
Bauang & 255.12 & $7,317.90$ & $/ 20 /$ & 0 & $13,543.65$ & 0 & $/ 4 /$ \\
Burgos & 0 & $4,944.50$ & $/ 14 /$ & 0 & $6,048.24$ & 0 & $/ 3 /$ \\
Caba & 735.12 & $6,267.85$ & $/ 16 /$ & 777.6 & $9,052.70$ & 0 & $/ 3 /$ \\
Luna & $5,400.94$ & $11,720.54$ & $/ 18 /$ & $5,443.20$ & $14,235.78$ & 0 & $/ 3 /$ \\
Naguilian & $2,220.47$ & $15,635.35$ & $/ 38 /$ & $2,332.80$ & $17,224.51$ & 0 & $/ 6 /$ \\
Pugo & $3,270.24$ & $6,768.45$ & $/ 10 /$ & $6,220.80$ & $5,977.45$ & 1 & 0 \\
Rosario & $1,500.47$ & $13,859.43$ & $/ 35 /$ & $3,888.00$ & $16,170.59$ & 0 & $/ 4 /$ \\
San Fernando City & 735.12 & $8,781.36$ & $/ 23 /$ & 777.6 & $14,062.75$ & 0 & $/ 4 /$ \\
San Gabriel & 750.24 & $7,458.57$ & $/ 19 /$ & 0 & $8,399.90$ & 0 & $/ 4 /$ \\
San Juan & 750.24 & $17,476.79$ & $/ 47 /$ & $1,555.20$ & $15,006.56$ & 0 & $/ 7 /$ \\
Sto. Tomas & 0 & $3,651.28$ & $/ 9 /$ & 777.6 & $8,470.68$ & 0 & $/ 2 /$ \\
Santol & 735.12 & $6,093.68$ & $/ 17 /$ & 0 & $8,156.08$ & 0 & $/ 3 /$ \\
Sudipen & $1,260.47$ & $7,676.90$ & $/ 18 /$ & $4,665.60$ & $11,199.86$ & 0 & $/ 1 /$ \\
Tubao & $4,815.12$ & $7,120.17$ & $/ 7 /$ & $6,998.40$ & $8,887.53$ & 2 & 0 \\
Total & $\mathbf{4 0 , 2 6 6 . 1 4}$ & $\mathbf{1 8 8 , 3 1 8 . 8 5}$ & $/ \mathbf{4 2 2 /}$ & $\mathbf{5 9 , 0 9 7 . 6 0}$ & $\mathbf{2 2 9 , 6 9 1 . 5 6}$ & $\mathbf{4}$ & $/ 61 /$ \\
\hline & & & & & & & \\
\hline
\end{tabular}

\section{Mechanization Level in the Province of La Union}

The mechanization level of tillage operation per municipality is in Fig. 2. It reveals that it ranges from $0.18 \mathrm{hp} / \mathrm{ha}$ to $3.52 \mathrm{hp} / \mathrm{ha}$ classified as low to highly mechanized. The municipalities which are categorized as highly mechanized include Bacnotan, Balaoan, Sudipen, and Naguilian with 3.57 hp/ha, $3.52 \mathrm{hp} / \mathrm{ha}, 3.33 \mathrm{hp} / \mathrm{ha}, 3.29 \mathrm{hp} / \mathrm{ha}$, respectively. The municipalities that are considered as moderately mechanized are Tubao $(2.55 \mathrm{hp} / \mathrm{ha})$,
Luna (1.94 hp/ha), Bagulin (1.76 hp/ha), Sto. Tomas (1.68 hp/ha), Rosario (1.36 hp/ha), Bangar (1.16 hp/ ha), and Caba (1.06 hp/ha). Lastly, the municipalities which are deemed as low mechanized are Pugo (0.64 hp/ha), City of San Fernando (0.54 hp/ha), Aringay (0.41 hp/ha), San Gabriel (0.19 hp/ha), and Santol $(0.18 \mathrm{hp} / \mathrm{ha})$. Although some municipalities are low mechanized, most rice farmers use mechanical power during tillage operation.

The planting operation mechanization 
level ranging from $0 \mathrm{hp} / \mathrm{ha}$ to $0.1 \mathrm{hp} / \mathrm{ha}$ is low mechanized. It could show that almost all municipalities do not utilize mechanical power during planting and employ human power or manual hand transplanting instead.

The harvesting operation mechanization level ranging from $0 \mathrm{hp} / \mathrm{ha}$ to $1.19 \mathrm{hp} / \mathrm{ha}$ is low to moderately mechanized. The municipalities with moderate classification are Agoo, Tubao, and Pugo with $1.19 \mathrm{hp} / \mathrm{ha}, 1.02 \mathrm{hp} / \mathrm{ha}$, and $0.97 \mathrm{hp} /$ ha, respectively, and the rest are low mechanized. It could show that almost all rice farmers employ manual power during the reaping of the harvest.

The drying and milling operations mechanization level range from $0 \mathrm{hp} / \mathrm{ha}$ to 0.05 $\mathrm{hp} / \mathrm{ha}$ and $0 \mathrm{hp} / \mathrm{ha}$ to $0.21 \mathrm{hp} / \mathrm{h}$, respectively. Both operations are low mechanized. Farmers either practice sun drying or immediately sell harvest without drying and milling.

In general, the rice farming mechanization level in the Province of La Union is $2.30 \mathrm{hp} / \mathrm{ha}$ as shown in Fig. 3. It is moderately mechanized due to the tillage operation at $1.73 \mathrm{hp} / \mathrm{ha}$ is the highest of all the rice operations and it has a surplus of machinery. On the other hand, for planting, it is $0.0023 \mathrm{hp} / \mathrm{ha}$, harvesting is $0.4958 \mathrm{hp} / \mathrm{ha}$, drying is $0.0218 \mathrm{hp} / \mathrm{ha}$, and milling is $0.0520 \mathrm{hp} / \mathrm{ha}$. All the operations are low mechanized and are found to have a deficit in machinery.

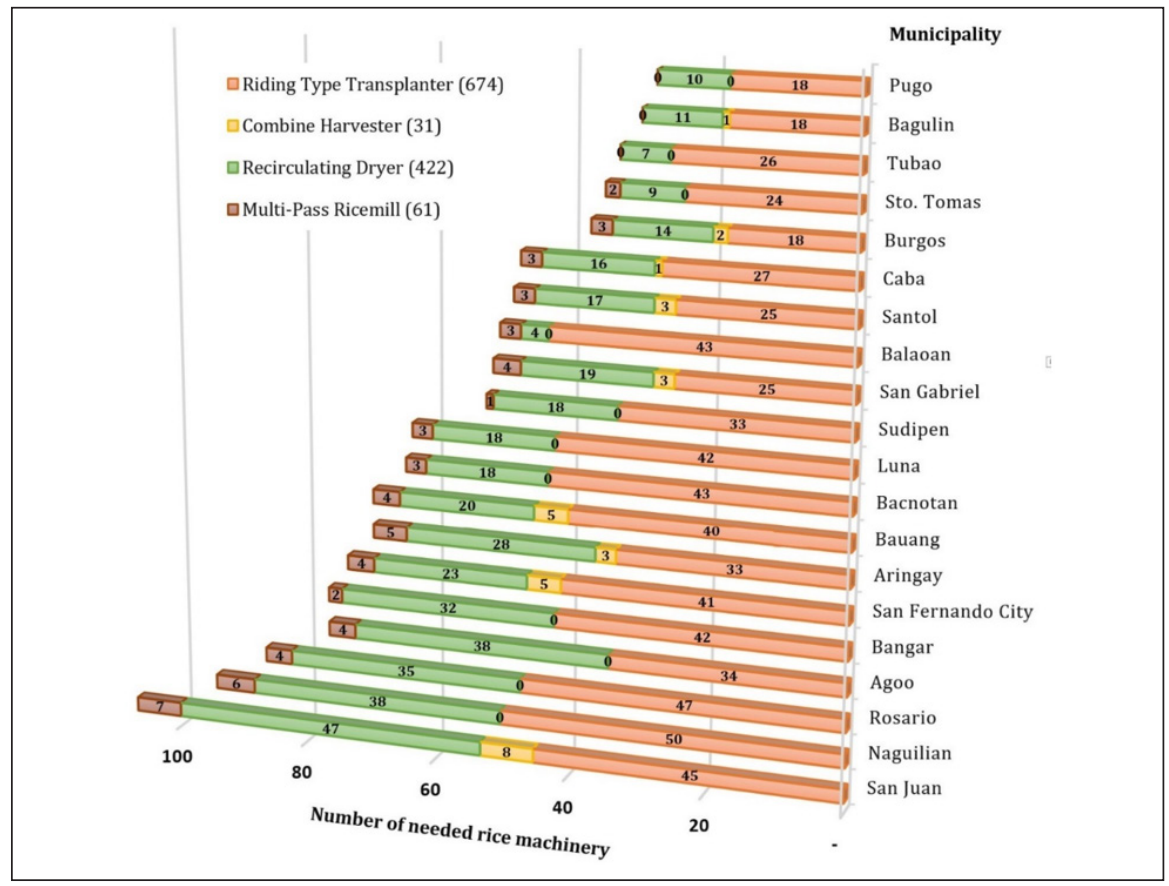

Figure 1. Total rice machinery requirement in the Province of La Union 


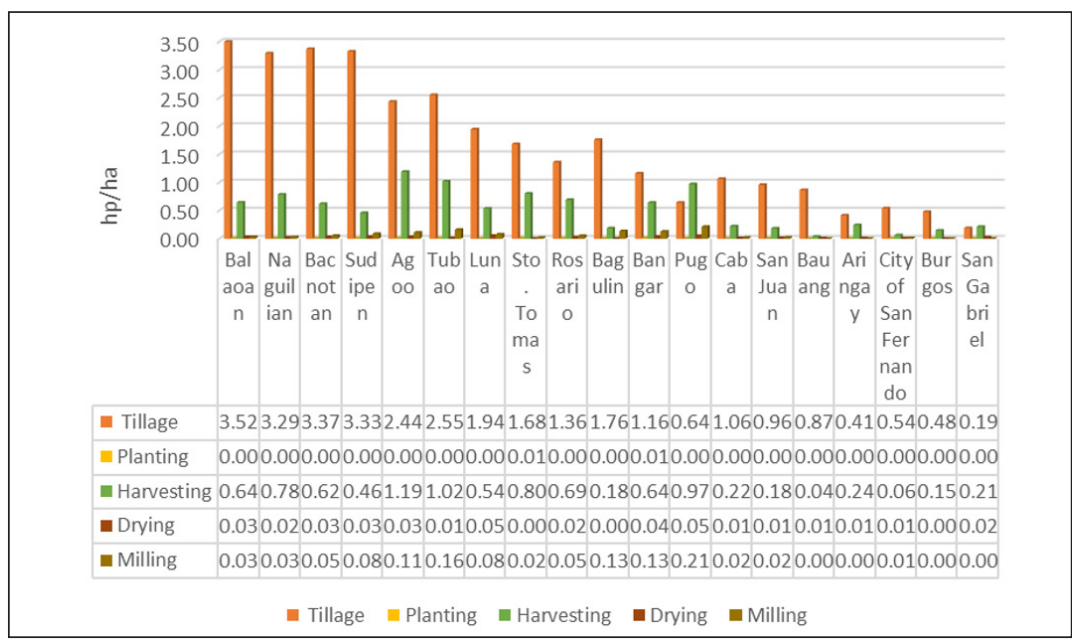

Figure 2. Mechanization level per municipality

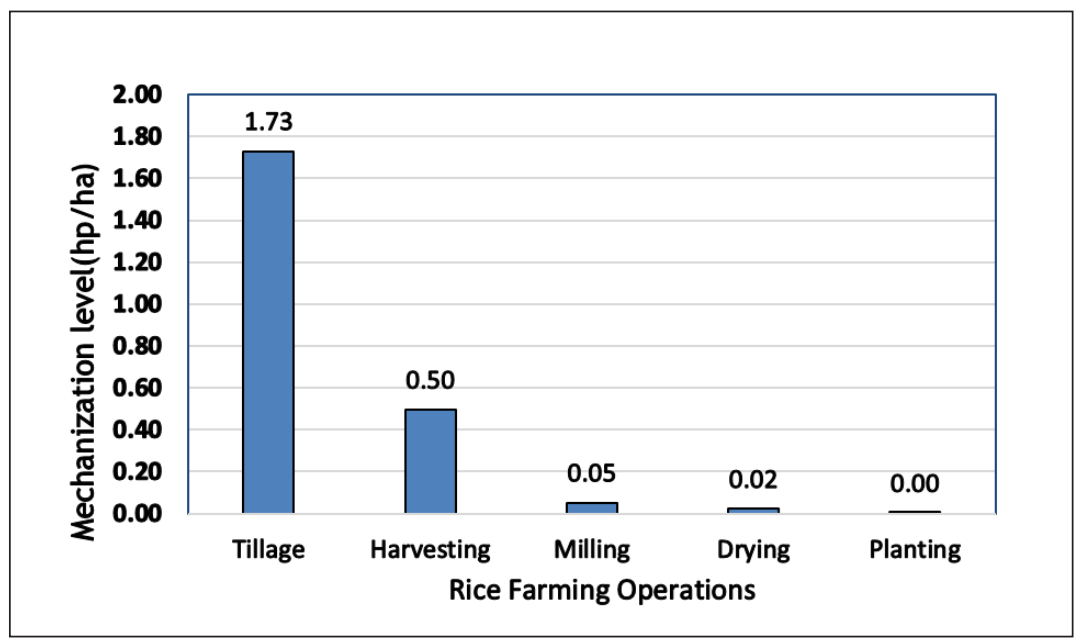

Figure 3. Overall provincial rice mechanization level

\subsection{Discussion}

The tillage operation in the province is found sufficient. Although some municipalities are deficit with tractors, it is encouraged that the tractors distributed to surplus municipalities be pulled out and be awarded to the deficit municipalities. Also, renting tractors to surplus municipalities could be implemented. Hence, the province will be able to maximize potentially and economically the available tractors and allocate deployment to other rice operations needing mechanization.

The manual hand transplanting has a duration of 20 to 30 man-days/ha and a labor cost of $\mathrm{P6}$, 000.00 to $P 8,000.00 /$ ha while using a mechanical transplanter has 5 to $6 \mathrm{hrs} / \mathrm{ha}$ and a rental of P6,123.00 (4-row riding-type transplanter) (Baradi \& Kang, 2018). Also, it maintains the correct spacing of seedlings that can increase yield by 25 to $40 \%$ over improper spacing associated with manual transplanting. These advantages could save money 
on inputs, labor, and materials ("Transplanting", n.d.). These benefits from manual to mechanical transplanting could support the province in fasttracking efficient and effective transplanting operation. The results reveal the immediate deployment of planting machinery. However, deployment must consider the topography and adaptability of designs of transplanters in the area. Thus, it is encouraged that walk-behind transplanters for highland municipalities and lowland municipalities with both walk-behind type and riding-type transplanters.

Manual harvesting has a total of $10.98 \%$ postharvest loss, of which harvesting is $4.85 \%$, piling is $2.06 \%$, and threshing is $4.07 \%$ (Dela Cruz \& Calica, 2016). These losses can be reduced by adopting mechanical harvesters such as rice reaper, thresher, and combine harvester. However, rice reaper still involves manual hauling and piling, and thresher involves manual cutting, hauling, and piling. The harvesting capacities of reaper and thresher of 4.56MT/day and thresher of 6.0 MT/day. This is far lower than the capacity of a rice combine harvester of $18.43 \mathrm{MT} /$ day. Thus, to eliminate manual handling, combat manual operations losses, and increase harvesting capacity, the rice combine harvester with minimum technical specification of postharvest loss of 3.5\% (Department of Trade and Industry, Bureau of Product Standards, 2015) is encouraged. While nine (9) municipalities are sufficient with harvesting machinery, still, 11 municipalities are deficit with machinery. Thus, the province is encouraged for harvesting machinery deployment. It is further encouraged to implement machine pooling or renting threshers to surplus municipalities and distribute them to deficit highland municipalities.

Drying accounts for a postharvest loss of as high as $8.70 \%$ of the total production (Ramos et al., 2013). The drying operation is so critical that inefficiencies or not immediate drying upon harvest would affect the shorter storage life of rice and poor milling recoveries. The practice of drying rice is through sun drying. However, the efficiency is affected by the unpredictability of the weather. In recognition of these critical roles of drying operation, the government promotes the use of mechanical dryers. The recirculating dryers and Multi-Purpose Drying Pavement (MPDP) are 6 MT/day capacity and flatbed dryers of 4.25 MT/day. However, sun drying during the rainy season is not operational using Multi-Purpose Drying Pavement (MPDP). Also, it needs a wide area of installation. Sun-drying is cheaper on the road. However, it results in rapid quality reduction and poor milling quality (Gummert, 2010). These types of dryers are labor-intensive. With this, recirculating dryers with higher capacity and less labor requirement are encouraged in the province. The results reveal that farmers immediately sell the harvest to the middlemen, traders, and private dryer operators. However, the selling price of freshly harvested rice at $P 17.22 / \mathrm{kg}$ is usually lower than that of dried rice at $P 19.91 / \mathrm{kg}$ (Department of Agriculture, 2020). Also, mostly the middlemen, traders are benefited compared to rice farmers (Mitchell, 2011). For these reasons, it is recommended that the province deploy drying machinery that could increase farmers' income, reduce drying losses, and prevent the mingling in rice prices.

The mechanization level for tillage operation is low to highly mechanized. This result agrees with Gavino et al. (2006) that farm operations in Regions 1,2 , and 3 are moderate to highly mechanized. The planting operation mechanization level is low mechanized. This result agrees with Manalon 
and dela Cruz (2018) that planting operation is low mechanized or predominantly using manual power. The harvesting operation is low to moderately mechanized. This result contradicts with Suministrado (2013) that harvesting operation is moderate to high mechanize. It could attribute to the insufficient intervention of harvesting machinery and unavailability of agricultural mechanization strategy in the province of La Union. The drying and milling operations are both low mechanized. This result agrees with Suministrado (2013) that drying and milling operations in the country are low mechanized.

\subsection{Conclusion \& Recommendations}

This study is conceptualized to formulate a scientific approach in determining the rice machinery requirement and the mechanization level in the province of La Union as the basis for prioritizing machinery deployment. The findings of moderately mechanized for tillage operation and low mechanized for transplanting, harvesting, drying, and milling operations signify a necessity for machinery intervention. Thus, there is a need of 674 units riding-type rice transplanter; 31 units combine harvester; 422 units recirculating dryer; and 61 units multi-pass rice mill. Accelerating the formulation of policy recommendations for budget programming and strengthening the gaps between the farmers and the concerned agencies are encouraged. Also, the crafting of Agricultural Mechanization Strategy (AMS) or Agricultural Mechanization Road Map to schedule the deployment, monitoring, and maintenance of acquired machinery is recommended.

\section{References}

Amare, D., \& Endalew, W. (2016). Agricultural mechanization: Assessment of mechanization impactexperiences on the rural population and the implications for Ethiopian smallholders. Engineering and Applied Sciences, 1(2), 39-48. https://doi.org/10.11648/j.eas.20160102.

American Society of Agricultural Engineers. (2000). ASAE EP496.2 DEC99: Agricultural machinery management. Academia. https://www.academia.edu/41779575/ S_T_A_N_D_A_R_D_ASAE_EP496_2_DEC99_ Agricultural_Machinery_Management

Amongo, R. M. C., Amongo, L. D., \& Larona, M.V. L. (2011, December 8-9). Mechanizing Philippine agriculture for food sufficiency [Paper presentation]. UNAPCAEM and FAO Roundtable Meeting on Sustainable Agricultural Mechanization in Asia, Bangkok, Thailand.

Baradi, M. A. U., \& Kang, C. (2018). Technical and financial assessment on the adaptation of transplanter and combine harvester in the llocos Provinces, Philippines. International Journal of Agriculture Innovations and Research, 6(4), 80-88. https://ijair.org/administrator/ components/com_jresearch/files/ publications/IJAIR_2678_FINAL.pdf

Bermudez, R. V., Matias, A. B., Tadeo, B. D., \& Manalili, R. G. (2004, April 22-23). Decision support system for rice mechanization: Preliminary study in the province of Nueva Ecija [Paper presentation]. 54th PSAE Annual Convention and Exhi-bition, Science City of Mu-ñoz, Nueva Ecija, Philippines.

Briones, R. M. (2017). Characterization of agricultural workers in the Philippines [Discussion Paper Series No. 2017-31]. Department of Agriculture. 
https://www.da.gov.ph/farmers-enjoy-highpalay-prices/

Casinillo, L. F. (2020). Econometric modelling on satisfaction in rice farming under Philippine rice tariffication law. Journal of Research and Multidisciplinary, 3(2), 326-336. https://doi. org/10.5281/jrm.v3i2.38

Dela Cruz, R., \& Bobier, S. B. (2016). Farm power available for utilization in Philippine agriculture. https://www.researchgate.net /publication/315783506_Farm_Power_ Available_for_Utilization_in_Philippine_ Agriculture

Dela Cruz, R., \& Calica , G. (2016). Postharvest losses in paddy and maize in major producing provinces of the Philippines: Stakeholders' perceptions. https://www.researchgate. net/publication/315783955_Postharvest_ Losses_in_Paddy_and_Maize_in_Major_ Producing_Provinces_of_the_Philippines_ Stakeholders\%27_Perceptions

Department of Agriculture. (2019). Adoption of the 2019 reference manual of agricultural machinery and equipment [Memo Order No. 02, series. 2020]. http://bafe.da.gov.ph / wpcontent/uploads/2020/05/MO-02-of-2020Adoption-of-the-2019-Reference-Manual-ofAgricultural-Mahineory-and-Equipment.pdf

Department of Agriculture. (2020). Farmers enjoy high palay prices. https://www.da.gov.ph/ farmers-enjoy-high-palay-prices/

Department of Trade and Industry, Bureau of Product Standards. (2015). Agricultural machinery - rice combine harvester -specifications [PNS/PAES 224:2015]. https://amtec.ceat.uplb.edu.ph/
wp-content/uploads/2019/07/PNS-PAES-2242015-Agricultural-Machinery-Rice-CombineHarvester-Specifications.pdf

Emami, M., Almassi, M., Bakhoda, H., \& Kalantari, I. (2018). Agricultural mechanization, a key to food security in developing countries: Strategy formulating for Iran. Agriculture and Food Security, 7(4). https://doi.org/10.1186/s40066018-0176-2

Exconde, B. A. (2016). Rice production and consumption trends in the Philippines from 2000 to 2015. https://xsite.dlsu.edu.ph/research/ centers/yc/_pdf/exconde-rice-production.pdf

FAO regional rice initiative pilot project Philippine. (n.d.). http://www.fao.org/fileadmin/ templates/agphome/scpi/Document_pdfs_ and_images/Presentation_RRI-Philippines.pdf

Food and Agriculture Organizations of the United Nations [FAO]. (2017). The future of food and agriculture: Trends and challenges. http://www. fao.org/3/i6583e/i6583e.pdf

Gavino, R.B., Fernando, C.M., Gavino, H. F., Sicat, E. V., \& Romero, M. M. (2006, April 17-21).Benchmark survey on farm mechanization status in irrigated lowlandsofRegion 1,2and3[Paperpresentation]. 4th PSAE International Convention and Exhibition, Balanghai Hotel, Butuan City, Philippines. https://www.researchgate. net/publication/299834723_Benchmark_ Survey_on_Farm_Mechanization_Status_in_ Irrigated_Lowlands_of_Regions_1_2_and_3

Gummert, M. (2010). Modern rice milling. International Rice Research Institute. http:// www.knowledgebank.irri.org/training/factsheets/postharvest-management/item/ 
modern-rice-milling-fact-sheet

Hanna, M. (2016). Estimating the field capacity offarm machines. lowa State University Extension and Outreach. https://www.extension.iastate.edu/ agdm /crops/pdf/a3-24.pdf

Hegazy, R. \& Okasha, M. (2020). Current perspective of mechanization level and its supporting policies in Asia. https://doi.org/ 10.6084/ m9.figshare.12780047.v1

Maheshwari, T., \& Tripathi, A. (2019). Quantification of agricultural mechanization status for Etawah District of Uttar Pradesh, India. International Journal of Current Microbiology and Applied Sciences, 8(5), 659-666. https://doi. org/10.20546/ijcmas.2019.805.077

Makange, N. (2015). The role of farm power in agriculture. https://doi.org/10.13140/ RG.2.1.4820.2722

Manalon, H. G., \& Dela Cruz, S.M. (2018). Onfarm mechanization of paddy in the Philippines. Asian Journal of Postharvest and Mechanization. https://www.researchgate. net/publication/327768462_OnFarm_ Mechanization_of_Paddy_in_the_Philippines

Mitchell, T. (2011). Middlemen, bargaining and price information: Is knowledge power? https:// www.tcd.ie/Economics/assets/pdf/JMPTara_ Mitchell1.pdf

Moya, P., Kajisa, K., Barker, R., Mohanty, S., Gascon, F., \& San Valentin, M. (2015). Changes in rice farming in the Philippines: Insights from five decades of a household-level survey. International Rice Research Institute. http://books.irri.org/97 89712203152_content.pdf
National Economic and Development Authority [NEDA]. (2019). More sources of cheaper rice with rice ratification- NEDA. https://www.neda. gov.ph/more-sources-of-cheaper-rice-withrice-tariffication-neda/

Palis, F.G. (2020). Aging Filipino rice farmers and their aspirations for their children. Philippine Journal of Science, 149(2), 351-361. https:// philjournalsci.dost.gov.ph/images/pdf/pjs_ pdf/vol149no2/aging_filipino_rice_farmers_. pdf

Philippine Council for Agriculture, Forestry, and Natural Resources Research and Development [PCARRD]. (2009). Agricultural mechanization in the Philippines. http://scinet.science.ph/ union/Downloads/BS\%20Agricultural\%20 Mechanization\%20in\%20the\%20Philippines_ beta_361500.pdf

Philippine Statistics Authority [PSA]. (2018). Agricultural import and exports [Report No. 2018-4]. https://psa.gov.ph/sites/default/files/ ais_Agri_exports $\% 20 \% 26 \% 20$ imports $\% 20$ 2018.pdf

Philippine Statistics Authority [PSA]. (2020). Trends in agricultural wage rates : 2017-2020. https://psa. gov.ph/sites/default/files/Report_2019\%20 Trends\%20in\%20Agri\%20Wage\%20Rates_ signed.pdf

Ramírez, A. O., Nakashima, H., Miyasaka J., \& Ohdoi K. (2007). Mechanization index and machinery energy ratio assessment by means of an artificial neural network: A mexican case study. Agricultural Engineering International, 9. https://ecommons.cornell.edu/bitstream/ handle/1813/10710/PM\%2007\%20002\%20 Aragon\%20final\%2024May2007.pdf\%3Bjsess 
ionid\%3D1F95840D9473AEF456B7B33C051A 2919?sequence\%3D1

Ramos, D. G., Vereña, R. O., Badua, A. E., Ligisan, A. R., \& Cayabyab, E. T. (2013). Promotion of biomassfed furnace retrofitted to mechanical dryers. Technical Bulletin, 3(1). https://www.philmech. gov.ph/assets/publication/Technical\%20 Bulletin/Technical\%20Bulletin\%20No.\%205. pdf

Regalado, J. \& Ramos, S. (2018). Field testing of a rice crop postharvest management protocol for reduced postproduction losses and improved product quality. Rice-Based Biosystems Journal, 4, 31-40. https://www.researchgate. net/publication/333649361_Field_Testing_ of_a_Rice_Crop_Postharvest_Management_ Protocol_for_Reduced_Postproduction Losses_and_Improved_Product_Quality

Sharabiani, R.V., \& Ranjbar, I. (2008). Determination of the degree, level and capacity indices for agricultural mechanization in Sarab Region. Journal of Agriculture, Science and Technology, 10, 215-223. https://www.researchgate.net/ publication/265821866_Determination_of_ the_Degree_Level_and_Capacity_Indices for_Agricultural_Mechanization_in_Sarab_ Region

Soni, P. \& Ou, Y. (2010). Agricultural mechanization at a glance selected country studies in Asia on agricultural machinery development. UN-ESCAP /UN-APCAEM. https://www.researchgate. net/publication/320014183_Agricultural_ Mechanization_at_a_Glance_Selected_ Country_Studies_in_Asia_on_Agricultural_ Machinery_Development_Agricultural_ Mechanization_at_a_Glance_in_Selected_ Country_Studies_in_Asia_on_Agricultural
Suministrado, D. (2013, October 26-27). Status of agricultural mechanization in the Philippines [Paper presentation]. Regional Forum on Sustainable Agricultural Mechanization in Asia and the Pacific, Qingdao, China. Retrieved from http://www.un-csam.org/ publication/2013RF/86-89.pdf

Transplanting. (n.d.). International Rice Research Institute. http://www.knowledgebank.irri.org/ step-by-step-production/growth/planting/ transplanting

University of the Philippines Los Banos. College of Engineering and Agro-Industrial Technology. Agricultural Machinery Testing and Evaluation Center. (2000). Philippine Agricultural Engineering Standards: PAES 109: 2000 - Agricultural machinery - walking-type agricultural tractor - specifications part 1: pulltype specifications. https://amtec.ceat.uplb. edu.ph/standards/per-volume/volume-1/

University of the Philippines Los Banos. College of Engineering and Agro-Industrial Technology. Agricultural Machinery Testing and Evaluation Center. (2001). Philippine Agricultural Engineering Standards: PAES 118: 2001Agricultural Machinery-four-wheel tractorspecifications. https://amtec.ceat.uplb.edu.ph/ production-machinery.

University of the Philippines Los Banos. College of Engineering and Agro-Industrial Technology. Agricultural Machinery Testing and Evaluation Center. (2015). Philippine national standard (PNS/PAES206::2015): Agricultural machinery -mechanical rice mill -specifications. https:// amtec.ceat.uplb.edu.ph/post-harvestmachinery/ 
University of the Philippines Los Banos. College of Engineering and Agro-Industrial Technology. Agricultural Machinery Testing and Evaluation Center. (2015). Philippine national standard (PNS/PAESv151:2015): Agricultural machinery -mechanical rice transplanter -specifications. https://amtec.ceat.uplb.edu.ph/productionmachinery/

University of the Philippines Los Banos. College of Engineering and Agro-Industrial Technology. Agricultural Machinery Testing and Evaluation Center. (2015). Philippine national standard (PNS/PAES204::2015): Agricultural machinery -mechanical rice reaper -specifications. https://amtec.ceat.uplb.edu.ph/productionmachinery/

University of the Philippines Los Banos. College of Engineering and Agro-Industrial Technology. Agricultural Machinery Testing and Evaluation Center. (2015). Philippine national standard (PNS/PAES204::2015): Agricultural machinery -mechanical rice thresher -specifications. https://amtec.ceat.uplb.edu.ph/productionmachinery/ 